\title{
インスリン分泌解析の新技術：生物発光法によるイメージングと定量解析
}

\author{
鈴木崇弘, ${ }^{*}, a$ 金森孝雄, ${ }^{a}$ 井上 敏 ${ }^{b}$
}

\section{Novel Technology for Studying Insulin Secretion: Imaging and Quantitative Analysis by a Bioluminescence Method}

\author{
Takahiro Suzuki, ${ }^{* a}$, Takao Kanamori $^{a}{ }^{a}$ and Satoshi Inouye ${ }^{b}$ \\ ${ }^{a}$ Department of Biochemistry, School of Dentistry, Aichi-Gakuin University; 1-100 Kusumoto-cho, Chikusa-ku, Nagoya \\ 464-8650, Japan: and ${ }^{b}$ Yokohama Research Center, JNC Co.; 5-1 Okawa, Kanazawa-ku, Yokohama 236-8605, Japan.
}

(Received January 17, 2020)

\begin{abstract}
We developed a method of video-rate bioluminescence imaging to visualize proteins secreted from living cells. A protein of interest was fused to Gaussia luciferase (GLase) , and the luminescence signals of secreted GLase with coelenterazine (luciferin) were visualized at a video-rate of $30-500 \mathrm{~ms} /$ frame by using a water-cooled EM-CCD camera. We established a subclonal rat INS-1E cell line, named iGL cells, stably expressing the fusion protein of insulin and GLase (Insulin-GLase). By stimulation with high glucose, 3D-cultured iGL cells showed synchronized oscillatory secretion of insulin for over $1 \mathrm{~h}$, as similarly observed in an isolated rat pancreatic islet. In 2D-cultured iGL cells, the luminescence images indicated that synchronized insulin secretion was localized in intercellular spaces between cells. Further, the relative amount of insulin secretion from iGL cells was easily determined with a luminometer, and we demonstrated that cell-cell interaction of beta cells is fundamental to increase glucose-stimulated insulin secretion by synchronization. Thus, iGL cells would be valuable for studying oscillatory insulin secretion and evaluating anti-diabetic drugs. Our bioluminescence imaging method with GLase could be generally used for investigating protein secretion in 2D and 3D cell culture systems.
\end{abstract}

Key words_ bioluminescence imaging; Gaussia luciferase; insulin secretion

\section{1.はじめに}

初夏の宵，山里の清流でホタルが光を放ち飛び交 う様子は趣がある。また夏の夜，海岸ではウミホ夕 ルや夜光虫の青い光を楽しむことができる. 生き物 が光を発する現象を, 生物発光（bioluminescence, バイオルミネッセンス）という。この発光現象は, ルシフェラーゼ (luciferase, 発光酵素) によって 触媒されるルシフェリン（luciferin，発光基質）及 び分子状酸素 $\left(\mathrm{O}_{2}\right)$ による酵素的酸化反応であり, ルシフェリンへの酸素添加・分解による化学反応の 過程で，光を発すると説明される。一般に生物発光 は観賞する楽しみがある一方, 医療研究に広く応用 されている.

$a$ 愛知学院大学歯学部生化学講座（干464-8650 名古屋 市千種区楠元町 1-100), ${ }^{b} \mathrm{JNC}$ 株式会社横浜研究所 (干236-8605 横浜市金沢区大川 5-1)

*e-mail: tsuzuki@dpc.agu.ac.jp

本総説は, 日本薬学会第 139 年会シンポジウム S 21 で

発表した内容を中心に記述したものである.
代表的なルシフェラーゼであるホタルルシフェ ラーゼは，主に遺伝子発現の解析に利用されてい る.また, 海洋生物由来の多様なルシフェラーゼ と, オワンクラゲのイクオリンに代表される発光タ ンパク質（photoprotein）は，多くのアッセイ系で 検出プローブとして使用されている. 一方，短波長 の励起光を吸収して長波長の光（蛍光）を発する蛍 光タンパク質 (fluorescent protein) は, オワンク ラゲ由来の green fluorescent protein (GFP) やサン ゴ由来の red fluorescent protein（RFP）について, 様々な蛍光色を持つ変異体が作製されており，主に 細胞内タンパク質の局在や動態の蛍光イメージング 解析に使用されている.

われわれは独自の技術として, 分泌型ルシフェ ラーゼをレポーターに用いる「分泌タンパク質の生 物発光イメージング法」を開発した。本手法は，細 胞表面の外側に輸送されるタンパク質の分子動態を 可視化する上で，多くの利点がある，本稿では，ビ デオレート生物発光イメージング法とルミノメー 
A

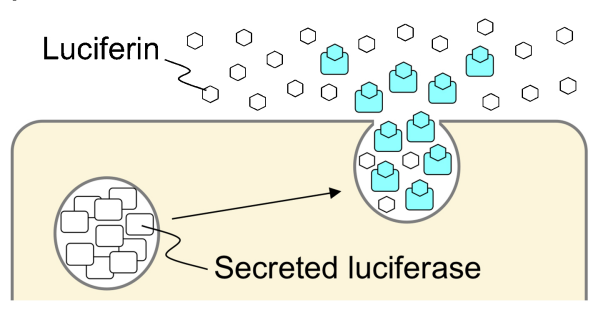

B

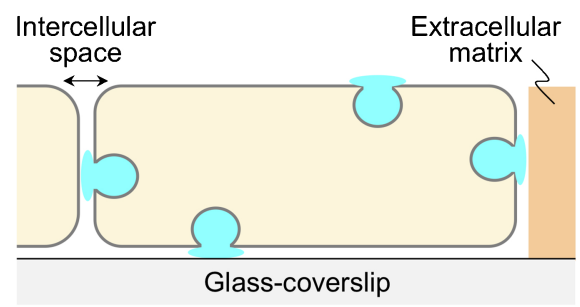

\section{Coelenterazine}

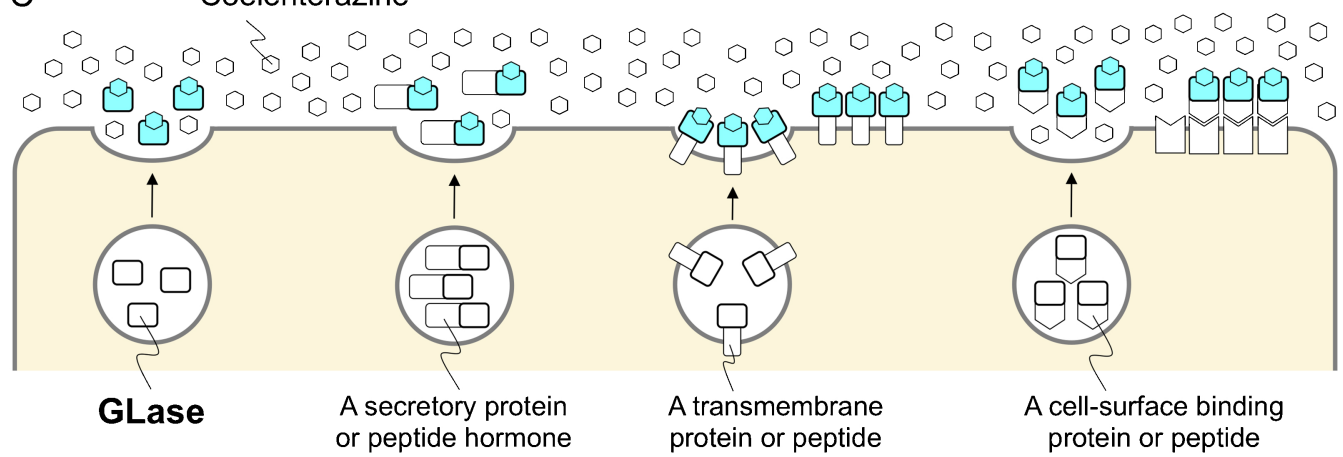

Fig. 1. Video-rate Bioluminescence Imaging of Proteins Secreted from Living Cells

Luminescence signals of GLase with coelenterazine (luciferin) on cell-surface were visualized at a video-rate of 30-500 ms/frame by using a water-cooled EMCCD camera. (A) Imaging principle of secreted protein by bioluminescence. Luminescence (cyan) was produced by the luciferin-luciferase reaction. (B) Detectable area of exocytosis. (C) Imaging principles of secreted proteins and membrane proteins on cell surface by using reporter proteins fused to GLase. (Color figure can be accessed in the online version.)

ターを用いた発光測定法による，インスリン分泌解 析の新しい技術を紹介する.

\section{2. 分泌タンパク質のビデオレート生物発光イ} メージング法

細胞は，成長因子，ホルモン，サイトカインなど の細胞間情報伝達物質や，細胞外マトリックス成分 とその調節に関与する酵素など，様々なタンパク質 を開口分泌（エキソサイトーシス）により細胞外へ 分泌している. 受容体や細胞接着分子など細胞表面 で機能するタンパク質も，これらを膜タンパク質と して含む輸送小胞が細胞膜に融合する形の開口分泌 により, 細胞表面に輸送される.

われわれは独自の技術として，「分泌タンパク質 の生物発光イメージング法」を開発してきた．本手 法は, 分泌型ルシフェラーゼ (発光酵素) がルシ フェリン（発光基質）を含む培養液に分泌された瞬 間に起こる酵素反応由来の微弱発光 [Fig. 1(A)] を, 高感度カメラ顕微鏡システムで可視化する. ${ }^{1)}$ この原理により, 生細胞の全細胞表面で開口分泌の 解析が可能であり [Fig. 1(B)], 細胞外の分泌夕ン パク質を特異的に検出して, 画像上の発光シグナル 強度から分泌量の変化を相対定量できる利点がある.

既知のルシフェラーゼの中で，コドンを最適化し た遺伝子を用いて哺乳類細胞で発現させた場合，高 発現し, かつ高い比発光活性を示すのは, 分泌型夕 ンパク質のガウシアルシフェラーゼ（Gaussia luciferase; GLase）である. ${ }^{2,3)}$ GLase はセレンテラジ ンを最もよい基質とし, 最大発光波長 $488 \mathrm{~nm}$ で比 較的広い半值幅 $(81 \mathrm{~nm})$ の発光スペクトルを有す る. ${ }^{4)}$ GLase は，分泌のためのシグナルペプチド (17 アミノ酸残基) を除いて 168 アミノ酸残基 （18.2 kDa）からなる分子量最小のルシフェラーゼ である. ${ }^{3-5)}$ また, GLase の発光活性には Cys 残基 の S-S 結合が必要と考えられ, ${ }^{5)}$ 細胞質に発現させ た GLase は，分泌経路に発現させた際の $1 / 500-$ $1 / 1000$ 程度の発光活性となる. ${ }^{2,6)}$ この性質に加え て，われわれの研究を含めて GLase を様々な分泌

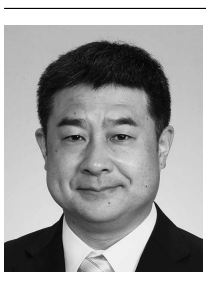

鈴木崇弘
愛知学院大学歯学部生化学講座教授. 1997 年東京大学大学院薬学系研究科博 士課程修了。藤田保健衛生大学総合医 科学研究所助手, 東京工業大学大学院 生命理工学研究科助手, 愛知学院大学 歯学部生化学講座講師, 同准教授を経 て, 2018 年 8 月より現職. 
タンパク質や膜タンパク質に融合させた解析例があ り，GLase は分泌経路に発現するタンパク質を解 析するためのレポーターに適している.

「分泌タンパク質の生物発光イメージング法」の 開発において，われわれは GLase をレポーターに 用いることで，CHO-K1 細胞における GLase の分 泌量が変動する様子を可視化した。 ${ }^{6}$ また, 細胞膜 貫通型シグナルペプチドと GLase の融合タンパク 質を発現させた神経様培養細胞では，脱分極に伴い 細胞表面のタンパク質量が増大する様子を可視化し た. ${ }^{6}$ 次に, いくつかの高感度カメラを試して顕微 鏡システムの構築を行いながら，細胞培養条件と GLase の生化学的性質を検討し，イメージング法 の時空間分解能を改善した. その結果，水冷の背面 照射型 EM-CCD カメラを備えた顕微鏡システムを 用いることで，個々の開口分泌で放出される GLase の発光シグナルを 30-500 ms/frame のビデ オレートで可視化した. ${ }^{7,8)}$ グルコース応答性インス リン分泌については，ヒトインスリンと GLase の 融合タンパク質（Insulin-GLase）をレポーターに 用いて，単一生細胞におけるインスリン分泌量の周 期変動（オシレーション）を可視化した. ${ }^{7)}$ また, プロ型で分泌され，細胞表面に結合して活性化され る細胞外基質分解酵素 MMP-2 については, MMP-2 と GLase の融合タンパク質（MMP2GLase）を用いて遊走 HeLa 細胞の進行方向（先導 端）における積極的な開口分泌を示した。 ${ }^{8)}$ また発 光パターンの違いから, 開口分泌中のタンパク質と 細胞表面に結合しているタンパク質の分布の違いを 示唆した. ${ }^{8)}$

一連の研究から, 生細胞のタンパク質分泌動態を 露光時間 30-500 ms/frame で可視化できる「ビデ オレート生物発光イメージング法」を確立した. ${ }^{9,10)}$ 分泌タンパク質やペプチドホルモン, 膜タンパク質 について，GLase 融合タンパク質をレポーターに 用いた生物発光イメージングを行うことで，個々の 開口分泌によるタンパク質の輸送動態や細胞表面で の局在を解析できる $[\mathrm{Fig} .1(\mathrm{C})]$.

\section{3. 細胞間で同調する周期性インスリン分泌の可} 視化

血糖値を抑制するペプチドホルモンであるインス リンは，血中グルコース濃度（血糖值）の上昇に伴 い，膵島（膵臓に多数存在する細胞塊）の大部分を
占める $\beta$ 細胞から分泌される， 2 型糖尿病では，血 中インスリン濃度の周期変動が膵 $\beta$ 細胞のインス リン分泌不全と標的細胞へのインスリン作用不全に 深く関与すると考えられるが，いまだ不明な点が多 い.インスリン分泌の可視化には，全反射蛍光 ${ }^{11,12}$ や 2 光子励起蛍光 ${ }^{13)}$ による蛍光イメージング法が応 用されており，それぞれ細胞のガラス接着面と細胞 間接着面で分泌小胞動態を観察できる利点がある一 方，膵島のような細胞塊全体の周期性インスリン分 泌を可視化する方法はなかった。したがって，膵島 と同様の周期性インスリン分泌動態を示す細胞株に ついても報告がなかった. 生物発光イメージング法 は可視化の原理上，対物レンズの倍率を限定するこ となく，単一細胞から細胞塊（スフェロイド）まで のタンパク質分泌動態を可視化できる．そこでわれ われは，Insulin-GLase をレポーターとするビデオ レート生物発光イメージング法でグルコース応答性 インスリン分泌を解析し [Fig. 2(A)]，細胞塊で同 調する周期性インスリン分泌を可視化した. ${ }^{14)}$

単離ラット膵島をマトリゲルコートしたガラスボ トムディッシュに接着させた後に, Insulin-GLase 発現用アデノウィルスで 24 時間感染させて生物発 光イメージングを行った $[$ Figs. 2(B) - (E) ]. その 結果, 高グルコース刺激から数分以内に, 膵島表層 全体が一斉に同調しながら周期変動する InsulinGLase 分泌の発光ビデオ画像を取得した。画像上 の発光強度解析により, 分泌量の周期変動は約 1 分 間隔であった [Figs. 2(D) and (E)]。一方，マトリ ゲルに接着した単一初代培養 $\beta$ 細胞の解析から, 高グルコース刺激による周期性インスリン分泌は, 一過性の 20 回以上からなる連続的な開口分泌によ ることが示唆された. ${ }^{14)}$

次に, 膵島様スフェロイド形成能とグルコース応 答性インスリン分泌の性質を有するラット $\beta$ 細胞 株 INS-1E 細胞を用いて生物発光イメージング解析 を行った. Insulin-GLase を一過性発現させた INS$1 \mathrm{E}$ 細胞では，遺伝子導入された多くの細胞がグル コース刺激によるインスリン分泌の増大を示すが, 拍動性の分泌を行う細胞はわずかであり，細胞間で 同調したインスリン分泌はみられなかった。

そこでわれわれは，Insulin-GLase 発現用プラス ミドベクター（pcDNA3-hINS-GLuc）を遺伝子導 入した INS-1E 細胞から Insulin-GLase 発現株のク 
A

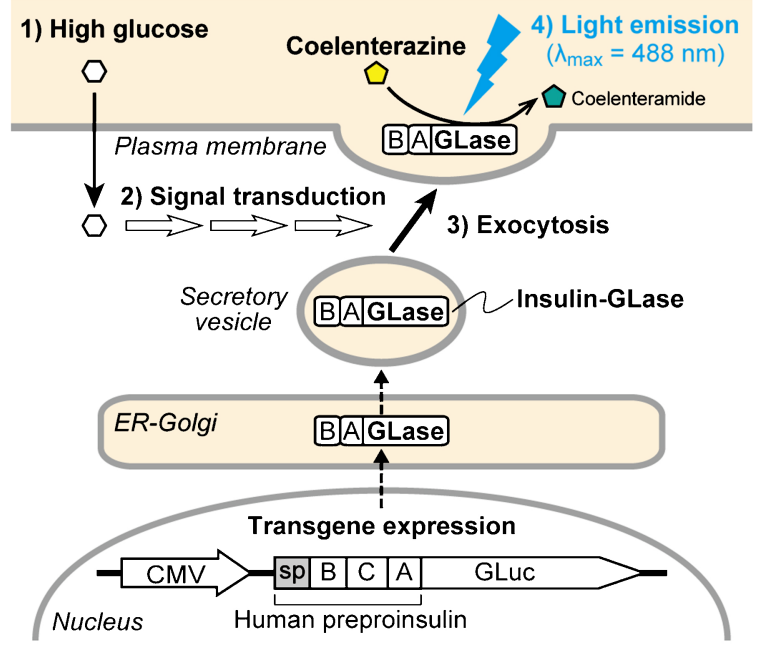

E

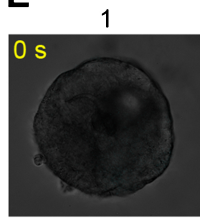

2

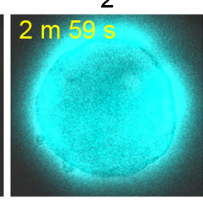

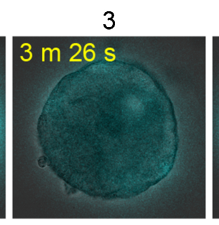

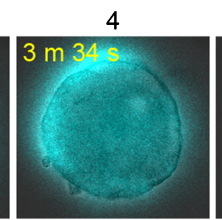

B

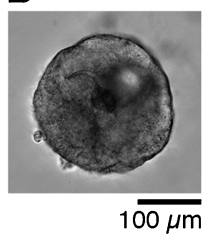

D

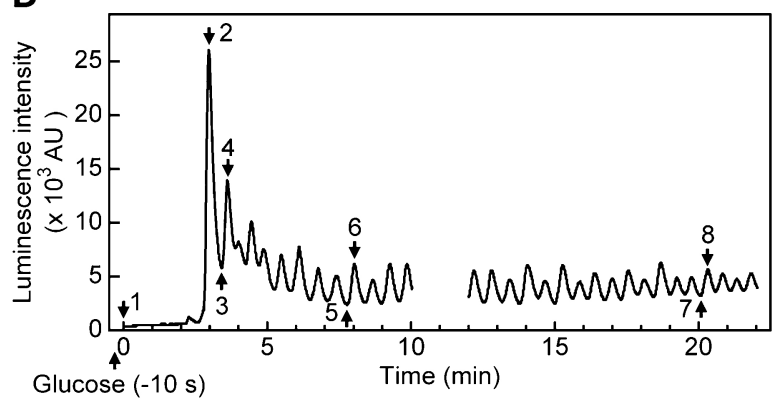

C

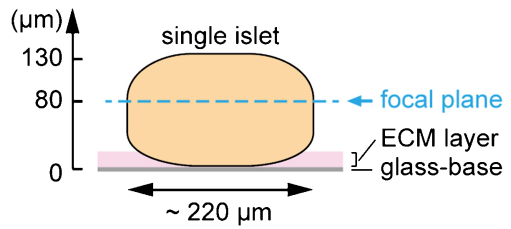

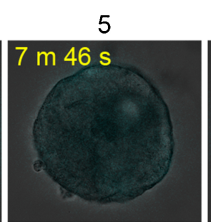
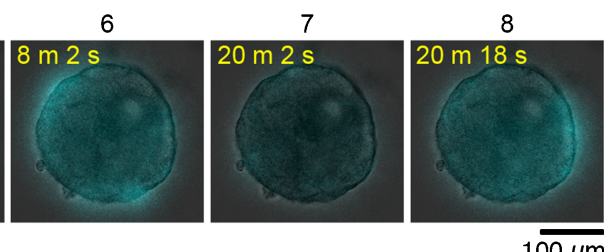

$1 \overline{100 \mu \mathrm{m}}$

Fig. 2. Video-rate Bioluminescence Imaging of Glucose-stimulated Insulin Secretion from an Isolated Rat Islet, a 3D Cell Cluster

(A) Schematic representation of bioluminescence imaging for glucose-stimulated insulin secretion using a fused protein of insulin to Gaussia luciferase (Insulin-GLase), and (B-E) video-rate bioluminescence imaging of insulin secretion from an isolated rat islet transiently expressing Insulin-GLase; (B) A bright-field image of a single islet attached on a glass plate, pre-coated with $4 \times$ diluted Matrigel solution as an extracellular matrix (ECM) gel. Objective lens, $20 \times$ (dry lens; N.A. 0.75 ), (C) Schematic representation of the focal plane in an islet for imaging. The focal plane was adjusted to $\sim 80 \mu \mathrm{m}$ from the surface of the glass plate, (D) Time-dependent changes of glucose-stimulated oscillatory insulin secretion in an islet. An isolated rat islet was pre-incubated for $2 \mathrm{~h}$ and washed with $2 \mathrm{mM}$ glucose in Krebs-Ringer Hepes buffer. After incubation with $20 \mathrm{mM}$ glucose for $10 \mathrm{~s}$ in the presence of coelenterazine $(3 \mu \mathrm{g} / \mathrm{mL})$, luminescence signals of Insulin-GLase were recorded with an exposure time of $500 \mathrm{~ms}$. Luminescence intensities of the video image were calculated, (E) Visualization of glucose-stimulated oscillatory insulin secretion from an islet. The luminescence images of secreted Insulin-GLase (colored cyan) are superimposed on the bright-field image of an islet in B. Each image numbered 1-8 is obtained from the acquisition points indicated by arrows numbered 1-8 in D. Reproduced from Fig. 1 in Suzuki et al. Biochem. Biophys. Res. Commun., 486 (4) , 886-892 (2017) under Elsevier's open access policies. (Color figure can be accessed in the online version.)

ローニングを行つた。薬剤耐性 $(200 \mu \mathrm{g} / \mathrm{mL} \mathrm{G} 418)$ による選別培養を行う中で, 細胞接着性ディッシュ 上で自然に形成された膵島様スフェロイドを分取 し，ルミノメーターを用いたグルコース応答性イン スリン分泌と，生物発光イメージング法による周期 性インスリン分泌を指標とした選別を行い，Insulin-GLase 定常発現細胞株として iGL 細胞を樹立 した.

ガラスボトムディッシュ（Iwaki，ノンコーティ ング）に二次元（2D）培養（平面培養）した iGL 細胞の生物発光イメージングでは, 細胞同士が接着 した集団で同調する拍動性のインスリン分泌が観察 され，開口分泌は細胞間接着部位に局在していた [Fig. 3(A)］。ノンコティングディッシュ上の 2D 培養では，高密度で 4 日間培養した際に細胞間の同 調性と周期頻度が高まり，20 倍又は 60 倍対物レン ズの観察視野全体でインスリン分泌が周期的に同調
する様子を示す，発光シグナルの伝播が繰り返し観 察された. ${ }^{14)}$

次に，三次元（3D）培養条件の $\mathrm{iGL}$ 細胞につい て生物発光イメージング解析を行った。細胞非接着 性ディッシュで 2 日間培養して細胞塊を形成させた 後に, ガラスボトムディッシュに 2 日間接着させて 層状の細胞塊 (3D cell layer) を形成させ，グルコー ス応答性インスリン分泌を解析した。 500 個程度の 細胞数からなる集団では，20 倍対物レンズの観察 で多くの細胞が焦点面に入り, 細胞塊全体が同調す る周期性インスリン分泌を示した [Fig. 3(B)]。画 像上の発光強度解析により, 分泌は約 1 分間隔で単 離膵島と同様の周期性を示し，周期性の分泌量変動 は 1 時間以上持続した. ${ }^{14)}$

さらに，スフェロイド形成用 96 ウェルプレート (PrimeSurface 96V plate, Sumitomo Bakelite) に 500 個の $\mathrm{iGL}$ 細胞を播種して 3 日間の培養で萃島様 
A

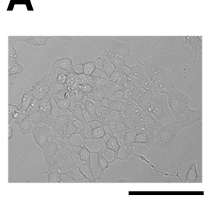

$\overline{100 \mu \mathrm{m}}$

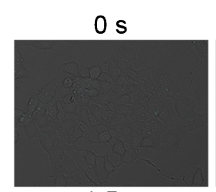

$1.5 \mathrm{~s}$

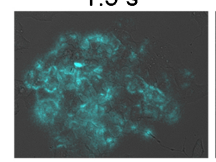

C

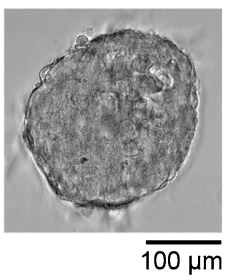

D
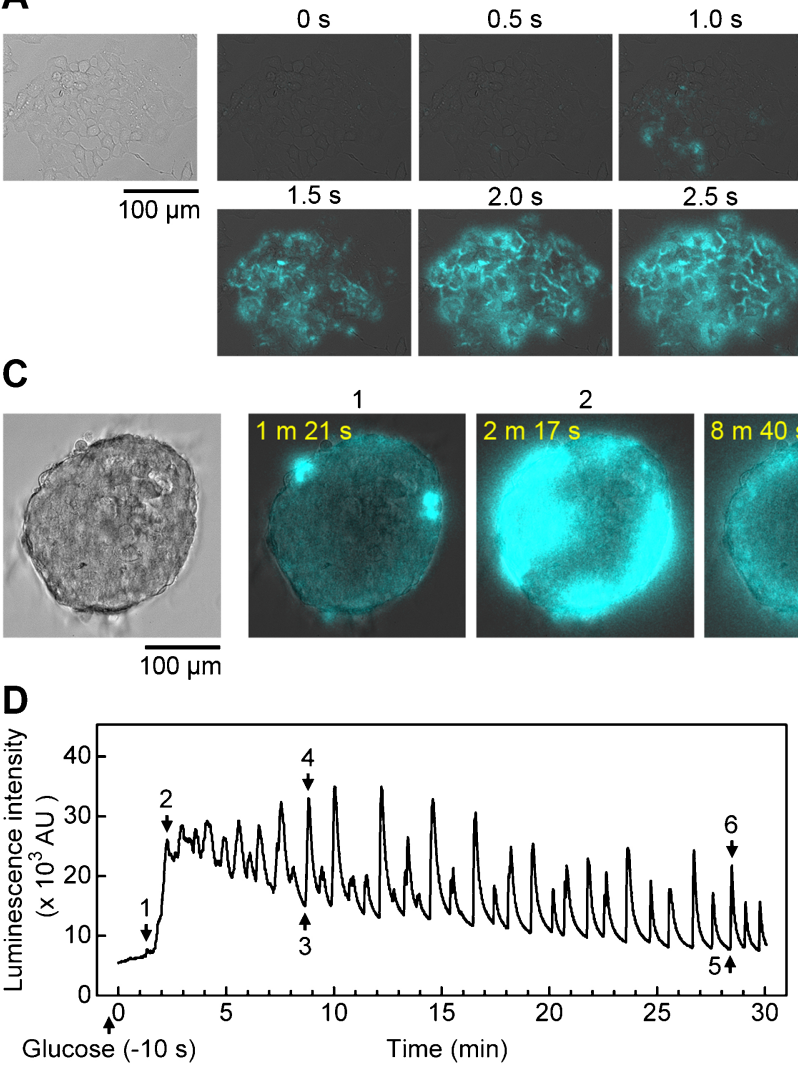

$2.0 \mathrm{~s}$

$2.5 \mathrm{~s}$

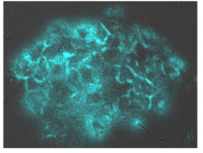

2
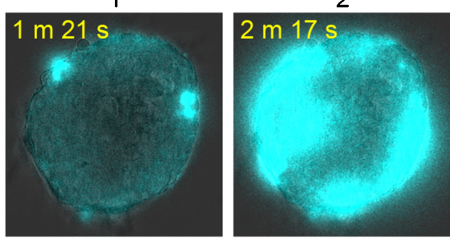

B
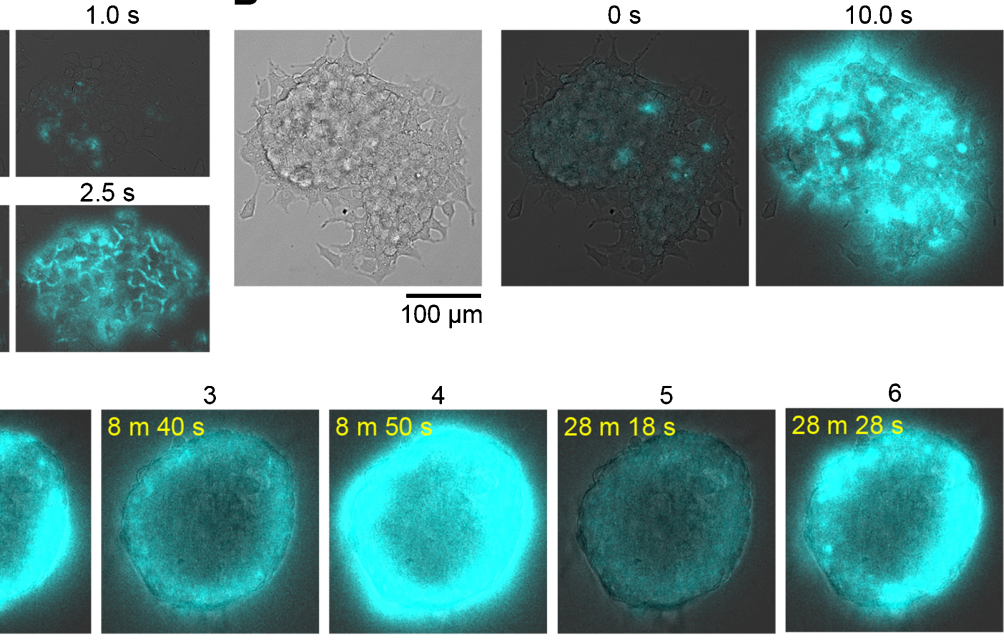

E

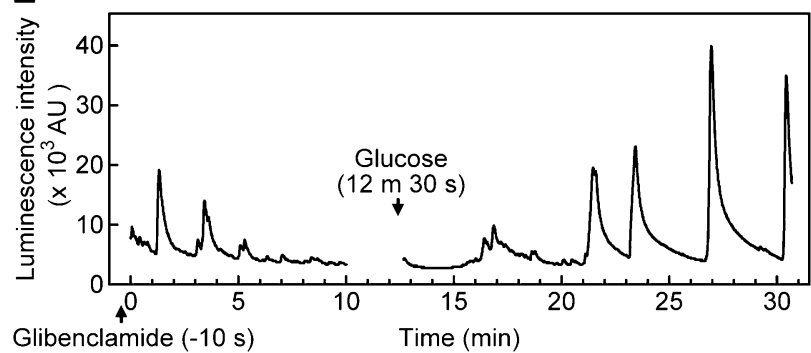

Fig. 3. Quantitative Visualization of Synchronized Oscillatory Insulin Secretion from 2D- and 3D-cultured iGL Cells

A clonal rat pancreatic beta cell line stably expressing Insulin-GLase (iGL cells) was used for glucose-stimulated insulin secretion analysis in 2D- and 3D-cultured iGL cells. After incubation with $20 \mathrm{mM}$ glucose (A-D) or $1 \mu \mathrm{M}$ glibenclamide (E) for $1 \mathrm{~min}$ (A), $20 \mathrm{~s}$ (B), and $10 \mathrm{~s}$ (C-E), luminescence signals of InsulinGLase were recorded with an exposure time of $500 \mathrm{~ms}$. Objective lens, $20 \times$ (dry lens; N.A. 0.75). (A-C) The luminescence images (colored cyan) are superimposed on the bright-field image of the cultured cells shown on the left; (A) Bioluminescence imaging of glucose-stimulated insulin secretion from 2D-cultured iGL cells. The image at $\mathrm{T}=0 \mathrm{~s}$ is at $1 \mathrm{~m} 41 \mathrm{~s}$ from the start of the recording, (B) Bioluminescence imaging of glucose-stimulated insulin secretion from $3 \mathrm{D}$-clustered iGL cells as a flattened cell layer. The images at $\mathrm{T}=0$ and $\mathrm{T}=10 \mathrm{~s}$ are at $2 \mathrm{~m} 35 \mathrm{~s}$ and $2 \mathrm{~m} 45 \mathrm{~s}$, respectively, from the start of the recording, (C) Bioluminescence imaging of glucose-stimulated insulin secretion from an islet-like spheroid of iGL cells. This spheroid was prepared as follows: After iGL cells (500 cells) were cultured in a non-cell adherent 96 -well plate for $3 \mathrm{~d}$, the formed spheroid was cultured for $24 \mathrm{~h}$ on a glass-bottomed dish coated with Matrigel to adhere to the glass plate. The images numbered 1-6 are at the indicated times from the start of the recording, (D) Time-dependent changes of glucose-stimulated insulin secretion from a spheroid of iGL cells. Luminescence intensities of the video image of $\mathrm{C}$ were calculated. The arrows numbered 1-6 indicate the acquisition points of the luminescence images for C. (E) Time-dependent changes of glibenclamide-stimulated insulin secretion from a spheroid of iGL cells, followed by the stimulation with $20 \mathrm{mM}$ glucose. Reproduced from Fig. 2 in Suzuki et al. Biochem. Biophys. Res. Commun., 486 (4), 886-892 (2017) under Elsevier's open access policies. (Color figure can be accessed in the online version.)

の細胞塊を形成させ，4 倍希釈したマトリゲルで コーティングしたガラスボトムディッシュに 24 時 間接着させて発光イメージング解析を行った.この 膵島様 iGL 細胞塊では, グルコース刺激の約 2 分 後からインスリン分泌の高い発光シグナルが観察さ れ，徐々に同調性がスフェロイド全体に広がり，刺 激後約 10 分以降は, 細胞塊全体が同調する周期性 分泌が観察され [Fig. 3(C)], 同調性は 1 時間以上 持続した。一方，糖尿病薬グリベンクラミドで刺激 した膵島様 iGL 細胞塊では, 刺激直後から 3 回程 度の部分的な同調性分泌が観察された後に, 徐々に 同調性が失われて約 10 分後にはほとんど分泌の発 光シグナルが検出されなくなつた. ${ }^{14)}$ その後, 高グ
ルコース刺激を行うと，グリベンクラミド前処理な しのスフェロイドの発光強度変化 [Fig. 3(D) ] と 比較して, 徐々に分泌量と同調性が高まる大きな周 期変動を示した $[$ Fig. 3(E) ].この結果から，グリ ベンクラミドはグルコース応答性インスリン分泌に おける細胞間の同調性と分泌の周期性を変化させる 可能性が示唆された.

4. グルコース応答性インスリン分泌における周 期性と分泌量の相関

2D 培養を行った iGL 細胞のグルコース応答性イ ンスリン分泌の発光ビデオ画像について [Figs. 4 (A) $-(\mathrm{C})]$, 発光最大值の合成画像を明視野画像 [Fig. 4(A)］に重ね合わせることにより，細胞間隙 

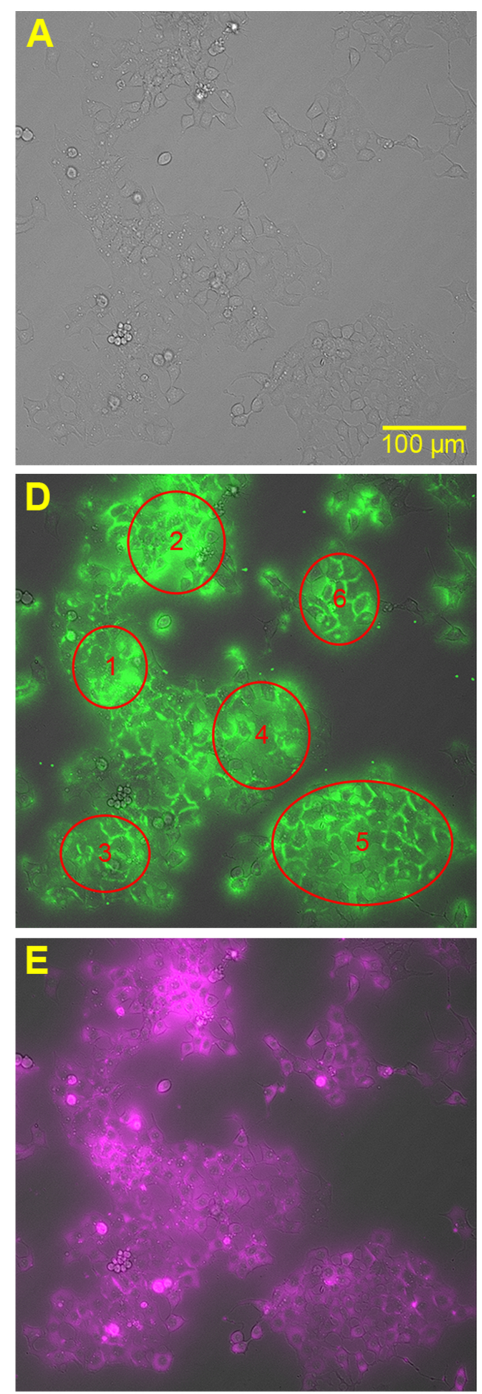
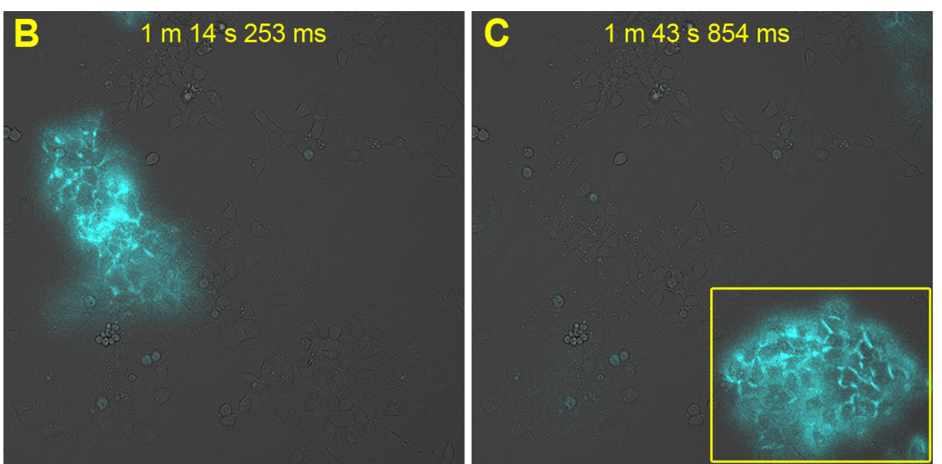

$\mathbf{F}$

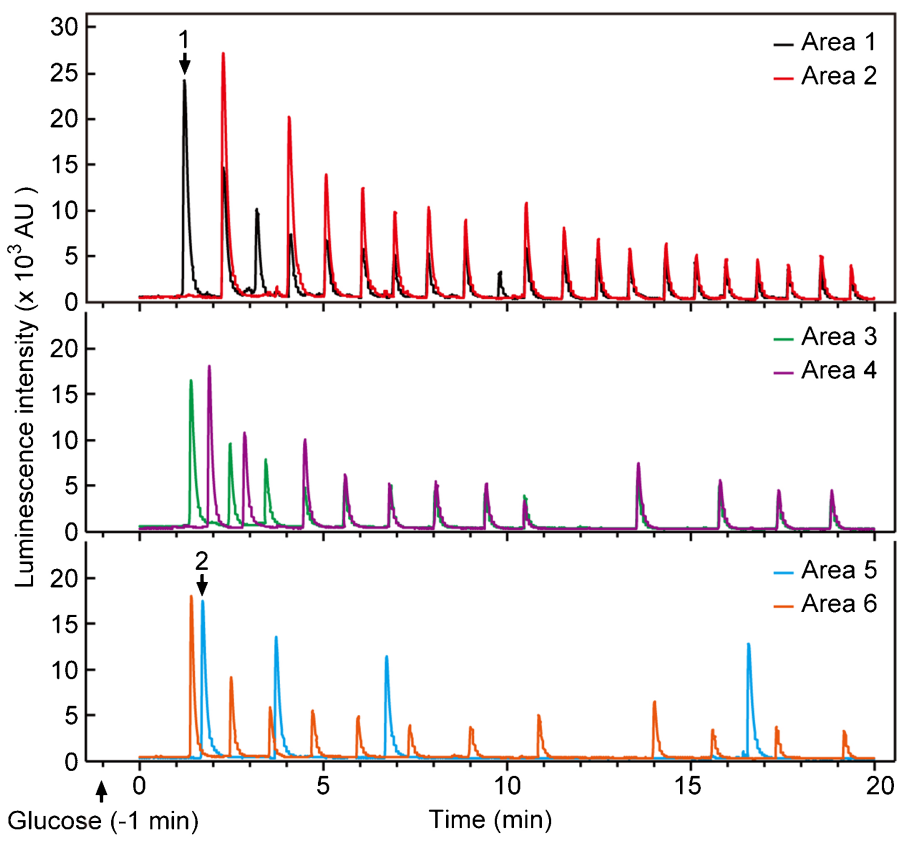

Fig. 4. Synchronized Oscillatory Insulin Secretion from a 2D-cultured Cell Cluster of iGL Cells Stimulated by High Glucose

iGL cells $\left(1 \times 10^{5}\right.$ cells) were pre-cultured on a glass-bottomed dish (Iwaki, without Matrigel) for $5 \mathrm{~d}$. After incubation with $20 \mathrm{mM}$ glucose for $1 \mathrm{~min}$, luminescence signals of Insulin-GLase secreted from iGL cells were recorded with an exposure time of $500 \mathrm{~ms}$ for $20 \mathrm{~min}$. Objective lens, $20 \times$ (dry lens; N.A. 0.75 ). (A) A bright-field image of iGL cells. (B, C) Luminescence images (colored cyan) superimposed on the bright-field image of A. The luminescence images of B and $\mathrm{C}$ are at $1 \mathrm{~m} 14 \mathrm{~s} 253 \mathrm{~ms}$ and $1 \mathrm{~m} 43 \mathrm{~s} 854 \mathrm{~ms}$, respectively, after the start of the recording. An area in yellow square in C was used for Fig. 2A. (D, E) The luminescence images of maximum (D) and average (E) intensities obtained from the luminescence video image. Luminescence signals of maximum and average intensities (colored green and magenta, respectively) are superimposed on the bright-field image of the cell. (F) Time-dependent changes of luminescence intensities in the imaging area of red circles (numbered 1-6) in D. The arrows numbered 1 and 2 indicate the acquisition points of the luminescence images for B and C, respectively. Reproduced from Fig. S4 in Suzuki et al. Biochem. Biophys. Res. Commun., 486 (4), 886-892 (2017) under Elsevier's open access policies. (Color figure can be accessed in the online version.)

への分泌局在が明確に示された [Fig. 4(D)]。また 発光平均值の合成画像では, ある程度の発光基質セ レンテラジンが細胞内に取り込まれたことによる細 胞内 Insulin-GLase 由来のわずかな発光と，分泌さ れた Insulin-GLase 由来の発光を合わせた，細胞内 外の発光シグナルが積算值相当として示される，発 光平均值合成画像を明視野画像に重ね合わせること により，すべての細胞で Insulin-GLase の発現が確 認され，細胞密度の高い領域が高い発光量を示した [Fig. $4(\mathrm{E})]$ 。 また, 発光強度の経時変化解析で
は, 細胞密度の高い領域で, 頻度の高い一定周期の インスリン分泌量変動を示した [Fig. 4(F)].

ルミノメーターを用いた発光測定による $2 \mathrm{D}$ 培養 した iGL 細胞の解析では, 細胞密度の高さと細胞 培養時間の長さに比例して，グルコース刺激による インスリン分泌の増大倍率と, 細胞あたりのインス リン分泌量が増加した（Fig. 5).

以上の結果から, 膵 $\beta$ 細胞間の接着は, 開口分 泌のホットスポット形成とインスリン分泌の周期性 に重要であり, 周期性インスリン分泌は分泌量の増 
A

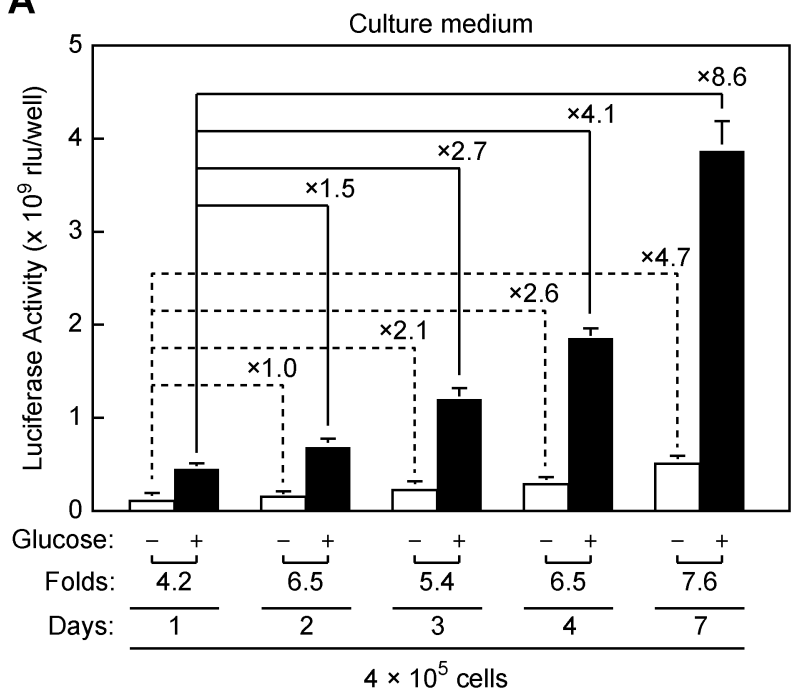

B

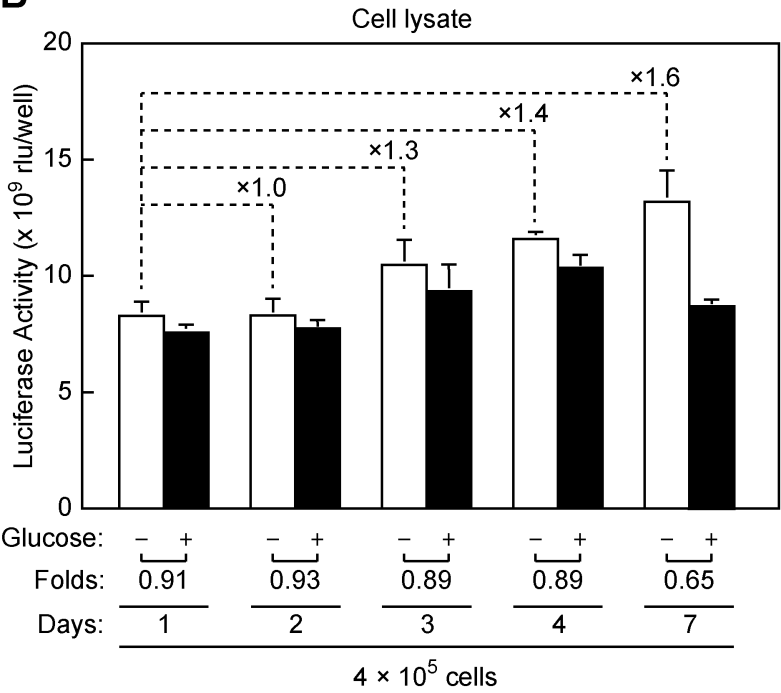

C

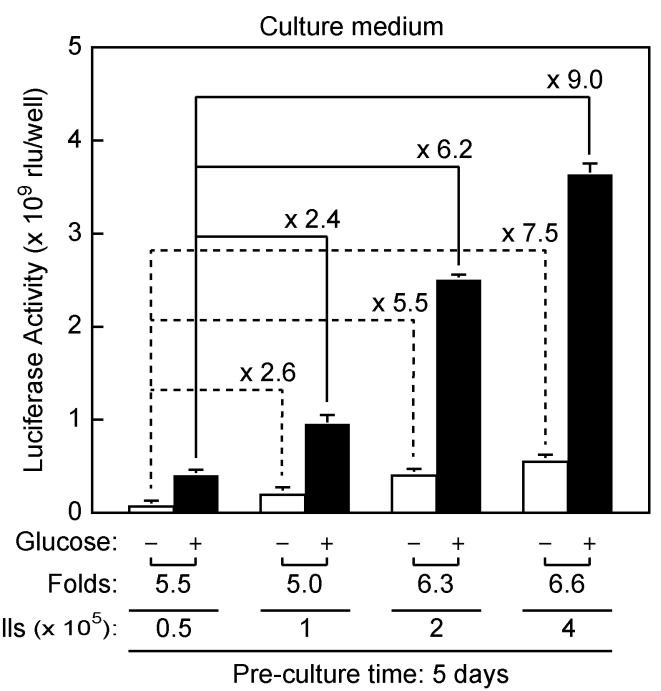

D

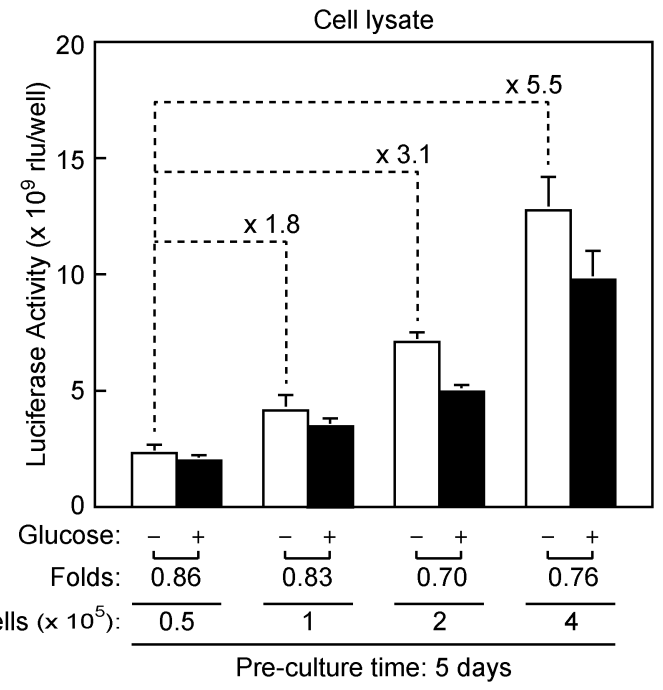

Fig. 5. Effect of Pre-culture Time and Cell Density on Glucose-stimulated Insulin-GLase Secretion from iGL Cells

iGL cells were seeded at various cell densities and cultured for various days in 6-well plates coated with poly-D-lysine. After starving with glucose for $1 \mathrm{~h}$, iGL cells were incubated in the presence or absence of $20 \mathrm{mM}$ glucose for $1 \mathrm{~h}$, and luminescence activities of Insulin-GLase in the cultured medium (A, C) and cell lysate (B, D) were determined using a luminometer. (A, B) Cells seeded at $4 \times 10^{5}$ cells per well and cultured for 1-7 d were used. For the $7 \mathrm{~d}$-cultured cells, the medium was changed on the 4 th day. (C, D) Cells seeded at $0.5-4 \times 10^{5}$ cells per well and cultured for $5 \mathrm{~d}$ were used. The medium was changed on the $3 \mathrm{rd}$ day. Reproduced from Fig. 4 in Suzuki et al. Biochem. Biophys. Res. Commun., 486(4), 886-892 (2017) under Elsevier's open access policies.

大に必要であることが示唆された。これにより, 2 型糖尿病における周期性インスリン分泌の消失 は，インスリン分泌不全の要因であると考えられた.

\section{5. iGL 細胞を用いたインスリン分泌解析の利点}

Insulin-GLase を定常発現する iGL 細胞は，高グ ルコース刺激により細胞集団全体で同調した周期性 インスリン分泌動態を示す特長を有している。 また iGL 細胞を用いた生物発光イメージングでは, 3D 培養条件でのインスリン分泌動態を解析できる利点 がある．膵島内で $\beta$ 細胞は多面体構造をとり, $\beta$ 細 胞間接着部位において面（Face）ではなく端
（Edge）に開口分泌を制御するタンパク質が集積す ることが報告されている。 ${ }^{15)} 2 \mathrm{D}$ 培養条件の iGL 細 胞では，周期性インスリン分泌において開口分泌は 細胞間接着部位に局在化しており，生理的な開口分 泌の動態と制御機構を解析する上で, iGL 細胞の生 物発光イメージングは有用と考えられる。一方，ビ デオレート蛍光イメージングはタイムラプス蛍光イ メージングと比較して，連続的な励起光の照射によ る細胞毒性と蛍光の褪色が問題となる. ビデオレー 卜生物発光イメージングでは励起光が不要であり, さらに, 発光基質セレンテラジンの細胞内への浸透 
は比較的遅いことから，iGL 細胞塊での周期性イン スリン分泌を 1 時間以上の発光ビデオ画像として取 得し, 画像上の発光強度から簡便に周期変動を相対 定量解析できる。

現在，インスリン分泌研究は主に抗体抗原反応を 利用した ELISA 法で解析されており，試薬キット が高価であることや実験時間の長さが問題となる. iGL 細胞を用いた場合，ルミノメーターを用いた発 光測定により簡便かつ安価にインスリン分泌の定量 解析が可能である. iGL 細胞からのインスリン分泌 については，ルミノメーターを用いた発光測定と ELISA による吸光度測定でグルコース刺激による 分泌量と誘導率に相関があることを確認している (未発表データ)。ルミノメーターを用いた iGL 細 胞の解析は，インスリン分泌の基礎研究と創薬研究 で有用と考えられる。

Insulin-GLase をレポーターとするインスリン分 泌解析を最初に報告した後, $\left.{ }^{8}\right)$ インスリンの Cペプ チドを GLase で置換したレポーターを用いた，ル ミノメーター測定による別のインスリン分泌解析が

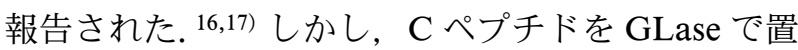
換したレポータータンパク質については，分泌経路 でのプロセッシングや発光活性の絶対值は不明であ る. ${ }^{16,17)}$ 一方，iGL 細胞を含む Insulin-GLase 分泌 系では，蛍光抗体染色とウェスタンブロット解析に より，インスリンは正確にプロセシングされて分泌 されることを確認している. ${ }^{8,14)}$ さらに, ウェス夕 ンブロット解析とルミノメーターを用いた発光測定 により，Insulin-GLase はインスリンと融合してい ない精製 $\mathrm{GLase}^{4)}$ と同等の発光活性を有することを 確認している（未発表データ）。iGL 細胞では，レ ポーターである Insulin-GLase のインスリンの適切 なプロセッシングと, GLase 発光活性によりイン スリン分泌解析を行うことができる.

\section{6. おわりに}

GLase をレポーターに用いた生物発光イメージ ング法は，細胞外に分泌されるタンパク質や細胞表 面に輸送される膜タンパク質を可視化できる上に, 感度，簡便性，定量性に優れる，ルミノメーターを 用いた発光測定法による定量解析との併用が可能と いう特長がある，近年の共同研究により，グルカゴ ン分泌動態, ${ }^{18)}$ マス卜細胞の脱顆粒現象, ${ }^{19)}$ トロン ビン受容体（プロテアーゼ活性型受容体，PAR-1）
の細胞表面におけるプロテアーゼによる切断20)につ いて，可視化と相対定量解析を報告している. さら に，生物発光を利用したセルベースアッセイは，蛍 光検出で問題となる薬物の自家蛍光を回避できる点 と高感度検出であることから，創薬研究での有用性 が高い．糖尿病研究におけるインスリン分泌の解析 を含めて, GLase の生物発光法による分泌タンパ ク質と膜タンパク質の可視化と定量解析には，研究 の広がりに大きな可能性を秘めている.

謝辞本内容に係わる共同研究を行つてきた多 くの方々に感謝申し上げます。

利益相反 井上 敏 ( JNC 株式会社の社員). その他の著者について，開示すべき利益相反はない.

\section{REFERENCES}

1) Inouye S., Ohmiya Y., Toya Y., Tsuji F. I., Proc. Natl. Acad. Sci. USA, 89, 9584-9587 (1992).

2) Tannous B. A., Kim D. E., Fernandez J. L., Weissleder R., Breakefield X. O., Mol. Ther., 11, 435-443 (2005).

3) Inouye S., Sahara-Miura Y., Sato J., Suzuki, T., Protein Expr. Purif., 109, 47-54 (2015) .

4) Inouye S., Protein Expr. Purif., 141, 32-38 (2018).

5) Inouye S., Sahara Y., Biochem. Biophys. Res. Commun., 365, 96-101 (2008).

6) Suzuki T., Usuda S., Ichinose H., Inouye S., FEBS Lett., 581, 4551-4556 (2007).

7) Suzuki T., Kondo C., Kanamori T., Inouye S., Anal. Biochem., 415, 182-189 (2011).

8) Suzuki T., Kondo C., Kanamori T., Inouye S., PLoS One, 6, e25243 (2011).

9) Suzuki T., Inouye S., Methods Mol. Biol., 1098, 71-83 (2014).

10) Suzuki T., Inouye S., Seikagaku, 86, 281-285 (2014).

11) Tsuboi T., Rutter G. A., Biochem. Soc. Trans., 31, 833-836 (2003) .

12) Ohara-Imaizumi M., Nagamatsu S., $J$. Biochem., 140, 1-5 (2006).

13) Takahashi N., Kasai H., Endocr. J., 54, 337346 (2007).

14) Suzuki T., Kanamori T., Inouye S., Biochem. 
Biophys. Res. Commun., 486, 886-892 (2017).

15) Geron E., Boura-Halfon S., Schejter E. D., Shilo B. Z., Cell Rep., 10, 317-325 (2015).

16) Burns S. M., Vetere A., Walpita D., Dančik V., Khodier C., Perez J., Clemons P. A., Wagner B. K., Altshuler D., Cell Metab., 21, 126-137 (2015).

17) Kalwat M. A., Wichaidit C., Nava Garcia A. Y., McCoy M. K., McGlynn K., Hwang I. H., MacMillan J. B., Posner B. A., Cobb M. H., ACS Sens., 1, 1208-1212 (2016).
18) Yokawa S., Suzuki T., Inouye S., Inoh Y., Suzuki R., Kanamori T., Furuno T., Hirashima N., Biochem. Biophys. Res. Commun., 485, 725-730 (2017).

19) Yokawa S., Suzuki T., Hayashi A., Inouye S., Inoh Y., Furuno T., Front. Cell Dev. Biol., 6, 74 (2018).

20) Kanki H., Sasaki T., Matsumura S., Yokawa S., Yukami T., Shimamura M., Sakaguchi M., Furuno T., Suzuki T., Mochizuki H., Cell Death Dis., 10, 100 (2019) . 